\title{
Razlike u prikupljanju migracijskih podataka: usporedba Hrvatske i odabranih europskih zemalja
}

DOI: https://doi.org/10.11567/met.35.1.1 UDK: 314.02:314.151.3-054.72(497.5)]:[314.02:314.151.3-054.72(4)

Prethodno priopćenje Primljeno: 31.10.2019. Prihvaćeno: 26.11.2019.

\section{Dario Pavić}

Odsjek za sociologiju, Hrvatski studiji, Sveučilište u Zagrebu, Zagreb dpavic@hrstud.hr

\section{Ida Ivanović}

\section{Zagreb}

ida0902@gmail.com

\section{SAŽETAK}

Iseljavanje iz Republike Hrvatske u razdoblju nakon pristupanja Europskoj uniji u središtu je interesa istraživača i javnosti, no točan broj iseljenika teško je utvrditi pomoću statističkih podataka o odjavama prebivališta u Republici Hrvatskoj. U ovom radu analiziraju se metode prikupljanja podataka o migracijskim tokovima u Hrvatskoj i šest europskih zemalja (Austrija, Irska, Italija, Njemačka, Norveška i Švedska), s posebnom pažnjom prema rokovima propisanima za prijavu uobičajenog prebivališta u pojedinoj zemlji. Isto tako uspoređuju se i brojevi iseljenih iz Hrvatske prema podacima Državnog zavoda za statistiku s podacima o useljenicima iz Hrvatske u spomenute zemlje. Postoje razlike u popisivanju migrantskih događaja među zemljama, a napose u Hrvatskoj, gdje nije jasan rok odjave kod dugotrajnijih boravaka $\mathrm{u}$ inozemstvu. Isto tako, utvrđeno je da je u velikom broju slučajeva broj prijavljenih hrvatskih državljana veći od broja iseljenih prema hrvatskim podacima. Iseljenici često nemaju poticaja odjaviti se iz Hrvatske zbog straha od gubitka stečenih socijalnih prava i nesigurnosti $u$ vezi s duljinom boravka $u$ inozemstvu. Broj prijavljenih hrvatskih građana u europskim zemljama veći je i zbog kraćeg roka obvezne prijave i jačih poticaja da se to učini. Nužno je usklađivanje hrvatskog sustava vođenja statistika s europskim praksama i uvođenje obuhvatnog registra stanovništva Republike Hrvatske.

KLJUČNE RIJEČI: iseljavanje, registar stanovništva, uobičajeno prebivalište, Hrvatska, migracijski tok

\section{UVOD}

Ujedinjeni narodi procjenjuju da je na globalnoj razini broj migranata, osoba koje ne žive u zemlji svoga rođenja, u 2019. godini dosegao 272 milijuna, 51 milijun više nego 2010., te da međunarodni migranti čine 3,5\% ukupnog 
stanovništva svijeta, za razliku od 2000. godine, kada su činili 2,8\% stanovništva. Među ova 272 milijuna nalazi se i 70 milijuna prisilnih migranata, najviše od uspostavljanja UNHCR-a prije 70 godina (Migration Data Portal, 2019a). U Europi prebiva 26\% svjetskih migranata, što je drugi najveći udio, odmah nakon Azije (30\%). Europske zemlje s najvišim brojem međunarodnih migranata u 2019. godini (isključujući Rusku Federaciju) jesu Njemačka (13,1 milijun), Ujedinjeno Kraljevstvo (9,6 milijuna), Francuska (8,3 milijuna) i Italija (6,3 milijuna) (Migration Data Portal, 2019a). Iako su kulturni, etnički, identitetski i rodni aspekti migracija snažni transformatori društva (Castles, de Haas i Miller, 2014: 55-81), ekonomski čimbenici, poput rasta trgovine i doznaka iz inozemstva, čine migraciju polugom međunarodnoga gospodarstva. Procjenjuje se da globalno desetpostotni porast broja migranata uzrokuje jedno i pol postotni prosječni rast trgovine (Genc i sur., 2012, prema Migration Data Portal, 2019b). Isto tako, procjenjuje se da će doznake koje imigranti šalju u zemlje porijekla u 2019. godini doseći 551 milijardu dolara, što je povećanje od 4,7\% u odnosu na 2018. (World Bank, 2019, prema Migration Data Portal, 2019c). Zbog svih navedenih podataka ne čudi snažna tvrdnja da je migracija »ključni način na koji ljudska bića djeluju da bi očuvali i povećali vlastito blagostanje« (Sander, Abel i Riosmena, 2014). Također, u uvjetima kada fertilitet $u$ većini zemalja opada, migracija postaje glavni demografski čimbenik prostornog razmještaja stanovništva unutar i izvan pojedinih država (Bilsborrow, 2016).

No unatoč globalnoj važnosti migracije, ne postoji konsenzus oko temeljne definicije migracije i s njome povezanih pojmova, kao ni jednoznačan i pouzdan način njezina mjerenja. Od tri temeljna demografska procesa (fertilitet, mortalitet i migracija) upravo migracija ima najnerazvijenije i najmanje standardizirane procedure prikupljanja i prikaza podataka (Bryan, 2004), pa pravila o tome variraju od zemlje do zemlje (Willekens, 2016), što uvelike onemogućava međunarodnu usporedivost migracijskih statistika (Edmonston i Michalowski, 2004). Usto, čini se da ne postoji ni neka natkriljujuća, opća teorija migracije, nego skup perspektiva i teorija srednjeg dometa (Brown i Bean, 2016), pa čak ni konsenzus o tome što migracija zapravo jest (Raymer, 2016).

Definicija migracije prema Ujedinjenim narodima jest »odlazak osoba iz mjesta njihova uobičajenog prebivališta, ili preko međunarodne granice, ili unutar države« (IOM, 2019). Bilsborrow (2016) navodi dva aspekta sadržana u UN-ovoj definiciji kao ključna: (1) promjenu mjesta uobičajenog prebivališta i (2) prelaženje priznate političke/administrativne granice. Koncept 
»uobičajenog prebivališta « pretpostavlja mjesto gdje osoba živi ili provodi dnevni odmor (IOM, 2019), slično kao i definicija u uredbi Europske unije (Uredba (EZ) br. 862/2007 Europskog parlamenta i Vijeća, 2007). ${ }^{1}$ Ta definicija »uobičajenog prebivališta odražava činjenicu da kraća izbivanja iz tog mjesta (turistička, zdravstvena, hodočasnička i sl.) nisu dovoljan razlog da bi se privremeni odlazak tretirao kao migracija, što je i uključeno u samu definiciju »uobičajenog prebivališta ${ }^{2}$ « prema EU-u (Uredba (EZ) br. 862/2007 Europskog parlamenta i Vijeća, 2007). No trajanje izbivanja iz mjesta uobičajenog prebivališta ključno je za definiciju migracije i povezano je s konceptom namjeravanog trajanja migracije (Bilsborrow, 2016). Prema Uredbi (EZ) br. 862/2007 Europskog parlamenta i Vijeća, imigraciju se definira kao "znači čin kojim osoba utvrđuje svoje uobičajeno boravište na državnom području države članice za razdoblje koje traje, ili se očekuje da će trajati, najmanje 12 mjeseci, a prethodno je imala uobičajeno boravište $\mathrm{u}$ drugoj državi članici ili u trećoj zemlji«.

U različitim državama Europske unije različiti su i načini i propisano razdoblje registracije useljenika, pa se utvrđivanje namjere prebivanja u državi duljeg od dvanaest mjeseci događa u različitim trenucima (Kupiszewska i Nowok, 2008). Dodatan je izazov i implementacija Preporuka UN-a o statistikama međunarodnih migracija (UN, 1998) u kojem se kao »kratkotrajni migranti« definiraju osobe koje u zemlji useljenja borave od 91 do 365 dana, dok se »dugotrajnim migrantima « smatraju oni koji u zemlji useljenja borave dulje od 365 dana. Iako razlikuje ta dva tipa migracija prema trajanju, UN preporučuje da se u godišnje statistike o imigracijskim tokovima uključe i »kratkotrajni migranti«. Opet, neke zemlje EU-a i EEA-e ne poštuju ove

Uredba (EZ) br. 862/2007 Europskog parlamenta i Vijeća od 11. srpnja 2007. o statistici Zajednice o migracijama i međunarodnoj zaštiti i o stavljanju izvan snage Uredbe Vijeća (EEZ) br. 311/76 o izradi statistike o stranim radnicima, Službeni list Europske unije, 16 (3), https://eur-lex.europa.eu/legal-content/HR/TXT/PDF/?uri=CELEX:32007R0862\&from $=$ it (13. 10. 2019.).

2 Engleski pojam usual residence prevodimo kao »uobičajeno prebivalište«, iako se u hrvatskom jeziku koriste još i »uobičajeno boravište« (kao u navedenoj Uredbi) i »uobičajeno mjesto stanovanja«. Budući da je ovo mjesto, tj. adresa definirana duljim prebivanjem, ili namjerom duljeg prebivanja (dulje od 12 mjeseci), bez obzira na kraća izbivanja, smatramo da je pojam »uobičajeno prebivalište « korektniji prijevod. Pomutnju izazivaju pojmovi prebivališta i boravišta, kako su definirani u hrvatskom Zakonu o prebivalištu i boravištu. Prema tom zakonu prebivalište je mjesto gdje se osoba trajno nastanila radi ispunjenja ekonomskih i inih ciljeva, a boravište je mjesto gdje osoba ispunjava iste ciljeve, ali ne trajnim prebivanjem. Problem je nedovoljno jasno određenje pojma »trajno«. $U$ Hrvatskoj osoba može imati prijavljeno boravište i dulje od 12 mjeseci, a svejedno imati drugo prebivalište. U većini zemalja EU ovo nije moguće jer osoba može imati samo jedno uobičajeno prebivalište, tj. jedno mjesto stanovanja (adresu). 
preporuke, tako da je $\mathrm{u}$ nekima rok $\mathrm{u}$ kojem se netko smatra rezidentom kraći, a u nekima duži (Kupiszewska i Nowok, 2008).

Nadalje, načini prikupljana podataka, ne samo o međunarodnoj migraciji nego i o ostalim demografskim događajima, razlikuju se od države do države. Broj međunarodnih migranata može se evidentirati na samoj granici, kao dio »statistika putnika«, zatim kao broj izdanih putovnica, radnih dozvola ili viza, kao broj povezan s promjenama u registrima stanovništva, kao broj dobiven u popisima stanovništva i periodičnim anketama stanovništva države, kao i u posebnim anketama doseljenog stanovništva (Edmonston i Michalowski, 2004). Svaki od tih načina ima svojih prednosti i mana, no smatra se da su dobro organizirani i financirani registri stanovništva »zlatni standard « za većinu demografskih i drugih podataka jer nude univerzalnu »pokrivenost« događaja od početka nečijeg života do smrti (Bilsborrow, 2016). Glavni je nedostatak periodičnih anketa pogreška uzorkovanja povezana s nedovoljno dobrim znanjem o cijeloj populaciji. Desetogodišnji popisi stanovništva pouzdano popisuju stanje broja migranata u nekoj državi, ali ne donose informacije o migracijskim tokovima. Jedna od posebno dvojbenih situacija kod popisa u zemljama emigracije jest nemogućnost dobivanja podataka o migrantima u slučajevima kada cijelo kućanstvo napušta teritorij države jer tada nema nikoga tko bi mogao dati informacije o članovima kućanstva koje se odselilo (Bilsborrow, 2016).

Cilj ovog rada jest usporediti načine prikupljanja podataka o migracijama i rokove za prijavu prebivališta u Hrvatskoj i odabranim europskim zemljama kako bi se objasnila diskrepancija statistika godišnjih migracijskih tokova prema podacima o iseljavanju iz Hrvatske i useljavanju u pojedinu europsku državu, i to u godinama nakon pristupanja Hrvatske Europskoj uniji. U tom smislu važno će biti identificirati način vođenja statistika o migracijskim tokovima (registri, ankete i dr.), kao i razdoblje koje pojedina država propisuje nakon kojeg je registracija kao stanovnika države nužna. Problem razlika u broju popisanih emigranata i imigranata već je prepoznat jer je migracija jedina demografska mjera koja se evidentira dvaput: u državi porijekla ${ }^{3}$ i u državi odredišta (Poulain, 2008). Odjava i prijava prebivališta ovise prvenstveno o odluci pojedinaca i vrlo su često podcijenjene u statistikama, posebno kod emigracije, gdje službene statistike često podcjenjuju stvarno stanje i do 90\% (Poulain, 2008). Smatra se da pojedinci imaju manje poti-

3 Ovdje je zemlja porijekla istovjetna engleskom pojmu country of origin i razlikuje se od zemlje rođenja (country of birth). Porijeklo označava državu - početnu točku emigracije u kojoj je osoba do tog trenutka imala prijavljeno uobičajeno prebivalište. 
caja odjaviti se iz zemlje porijekla nego prijaviti se u zemlju odredišta pa su zato statistike odseljavanja niže od onih useljavanja (Reeger, 2009). Kod iseljavanja iz Hrvatske dodatan je problem nepoznat broj građana Republike Hrvatske koji prebivaju u susjednim državama, posebice Srbiji i Bosni i Hercegovini, a koji se odseljavaju u europske zemlje i ulaze u statistike ulaska iz Hrvatske. Iako u rezultatima razlikujemo useljenje prema državljanstvu i prema zemlji porijekla, problem su hrvatski građani iz susjednih država koji imaju prijavljeno prebivalište u Hrvatskoj, a sukladno tomu i putne isprave s hrvatskom adresom, a koji zapravo prebivaju u susjednim državama (tzv. fiktivna prebivališta u RH). Takve građane nije moguće razlikovati od »stvarnih « stanovnika Hrvatske ni po državljanstvu ni po državi porijekla jer je u oba slučaja to Hrvatska. U fokusu ovog rada jest identificiranje najvjerojatnijeg izvora pogrešaka u statistikama o odseljavanju iz Hrvatske i useljavanju u europske zemlje. Ono što nije fokus rada jesu procjena stvarnog broja odseljenih iz Hrvatske, kao ni analiza razloga iseljavanja iz Hrvatske u postpristupnom razdoblju. Modeli procjene migracijskih tokova pomoću podataka iz države odseljavanja i države useljavanja razvijeni su u posljednjih nekoliko godina (Raymer i sur., 2013), no takav pokušaj ostavljen je za neko sljedeće istraživanje. O motivima iseljavanja iz Hrvatske postoje recentna istraživanja (Jurić, 2017; Rajković Iveta i Horvatin, 2017), kao i o općim, gospodarskim i obrazovnim posljedicama iseljavanja (Župarić-Iljić, 2016).

\section{PODACI I METODE}

Budući da je općeniti cilj ovog istraživanja istražiti suvremene migracije građana Hrvatske u zapadnoeuropske države, odabrano je razdoblje od 2013., kao godine pristupanja Hrvatske Europskoj uniji, do 2018., posljednje godine za koju su dostupni podaci o iseljavanju iz Hrvatske i useljavanju u odabrane države. Za analizu je odabrano šest država: Austrija, Italija, Irska, Njemačka, Norveška i Švedska. Sve odabrane države, osim Norveške, članice su EU-a, a sama Norveška dio je Europskoga gospodarskog prostora (EEA). Austrija i Njemačka, a donekle i Italija, Norveška i Švedska, povijesno su zemlje useljavanja hrvatskih građana, s ustanovljenim i aktivnim hrvatskim zajednicama. Sve su istraživane države jaka gospodarstva, što je jedan od najvažnijih privlačnih čimbenika za useljavanje stranog stanovništva. Isto tako, izražene su i kulturne veze između Hrvatske i posebice Austrije, Njemačke i Italije. Irska je privlačna hrvatskim državljanima i zbog službenog jezika (engleski), propisa koji stimuliraju imigraciju i većinskoga katoličkog stanovništva. Švedska i Norveška, osim jakosti gospodarstva, 
posebice su privlačne hrvatskim građanima zbog sveobuhvatnog sustava socijalne zaštite i inkluzije. Osim prema tim kriterijima države su odabrane i prema različitim načinima vođenja statistika o migracijskim tokovima, kao što će se pokazati dalje u tekstu.

Za analizu dinamike suvremenih migracija hrvatskog stanovništva odabrana je metoda analize migracijskih tokova (migration flows), koji se najčešće prikazuju kao broj useljenika (imigranata) i iseljenika (emigranata) određene države u jednoj kalendarskoj godini. Smatramo da je ova metoda primjerena zbog kratkoga istraživanog razdoblja i pojačane dinamike odseljavanja hrvatskog stanovništva u tom razdoblju. Analiza se sastoji od dva dijela: od komparativne analize popisnog zakonodavstva i načina registracije godišnjeg broja useljenika/iseljenika, koja uključuje načine prikupljanja podataka i propisane rokove za registraciju boravišta/prebivališta, i od analize matrica dvostrukog unosa (double-enty matrices), tj. usporedbe broja registriranih iseljenika iz pojedine države (u ovom slučaju Hrvatske) i broja useljenika u neku drugu državu. U ovom istraživanju ta usporedba provedena je za svaku godinu, za kombinaciju hrvatskih podataka o iseljenicima i podataka svake od navedenih država o useljenim hrvatskim državljanima, kao i o osobama kojima je zemlja porijekla bila Hrvatska. Izračunala se razlika između pojedinih godišnjih kombinacija podataka, kao i udio hrvatskih podataka o iseljenicima u broju useljenika za pojedinu državu, jer je najčešće registrirani broj iseljenika iz Hrvatske manji od registriranog broja useljenika iz Hrvatske u nekoj od analiziranih država.

Podaci o načinima registracije useljenika/iseljenika u pojedinoj državi dobiveni su sa službenih internetskih stranica središnjih državnih ureda za statistiku istraživanih država, prvenstveno iz metodoloških objašnjenja koja upućuju na zakonski okvir registracije useljenja/iseljenja. Podaci o useljenim hrvatskim državljanima u pojedinoj godini za Italiju, Njemačku, Norvešku i Švedsku dobiveni su pretragom internetskih stranica nacionalnih središnjih ureda za statistiku, dok podaci za Austriju nisu javno dostupni, nego su dobiveni na zahtjev autora, putem e-pošte. Podaci za Irsku ne diferenciraju hrvatske državljane u službenim statistikama, pa je njihov broj procijenjen putem izdanih PPS (PPSN, Personal Public Service Number) brojeva koje izdaje Odjel za zapošljavanje i socijalnu zaštitu Republike Irske. Broj osoba koje su se uselile u određene države iz Hrvatske kao zemlje porijekla bio je dostupan za Italiju, Njemačku, Švedsku i Norvešku također preko službenih internetskih stranica nacionalnih središnjih ureda za statistiku. Broj odseljenih hrvatskih državljana prema istraživanim zemljama dobiven 
je sa službenih internetskih stranica Državnog zavoda za statistiku Republike Hrvatske.

Rezultati komparativne analize načina popisivanja useljenika/iseljenika prikazat će se kao kratki opisi nacionalnih zakonskih odredaba o ovoj tematici, a zbog lakše usporedbe načini prikupljanja podataka i rokovi za registraciju useljenja/iseljenja navest će se i u tablicama. U tablicama će se navesti i kombinacije službenog broja odseljenih iz Hrvatske i useljenih hrvatskih državljana u pojedinu državu, za svaku godinu, s već navedenom razlikom i udjelom. Zbog spomenutoga problema hrvatskih državljana koji ne prebivaju u Hrvatskoj navest će se i analogni podaci za one osobe koje su se u pojedinu državu uselile iz Hrvatske, gdje za to postoje podaci.

\section{REZULTATI}

Za ovu analizu relevantne su zakonske odredbe o registraciji osoba koje se privremeno ili trajno iseljavaju iz republike Hrvatske navedene u Zakonu o prebivalištu (NN, 144/12). Taj zakon razlikuje pojmove prebivališta (mjesto trajnog nastanjenja) i boravišta (mjesto privremenog nastanjenja, u pravilu dulje od tri mjeseca). Članak 3. ovog zakona navodi da je osoba koja se »iseljava iz Republike Hrvatske radi trajnog nastanjenja u drugoj državi dužna odjaviti prebivalište. Odjava prebivališta podnosi se prije iseljenja. Ako osoba propusti odjaviti prebivalište prije iseljenja, odjavu mora zatražiti u roku od 15 dana od dana useljenja u drugu državu putem nadležne diplomatske misije - konzularnog ureda Republike Hrvatske u toj državi«. No ako se osoba ne namjerava trajno iseliti, nego privremeno boraviti u inozemstvu, formulacija $\mathrm{u}$ istom članku ovakva je: »Ako osoba napušta prebivalište $\mathrm{u}$ trajanju duljem od godinu dana radi privremenog odlaska izvan Republike Hrvatske u svrhu obrazovanja, obavljanja poslova koji nisu trajnog karaktera i vezani su za određeno vremensko razdoblje, dugotrajnog liječenja i drugih razloga dužna je to prijaviti nadležnom tijelu na čijem području ima prijavljeno prebivalište, neposredno ili putem nadležne diplomatske misije - konzularnog ureda Republike Hrvatske u inozemstvu, uz prilaganje odgovarajuće dokumentacije o razlozima privremenog odlaska« (Zakon o prebivalištu, $N N, 144 / 12)$.

S druge strane, definicija odseljenog i doseljenog stanovništva prema publikacijama Državnog zavoda za statistiku jest da je to ono stanovništvo »koje je promijenilo uobičajeno mjesto stanovanja na području Republike Hrvatske ili koje je promijenilo uobičajenu državu stanovanja na razdoblje koje je 
ili se očekuje da će biti dugo najmanje godinu dana (Statistički ljetopis Republike Hrvatske 2018.). Prema Zakon o prebivalištu (NN, 144/12), prebivalište i boravište prijavljuju se u policijskim upravama ili postajama MUP-a. Policija može terenskim uvidima provjeravati status boravišta i prebivališta, a kazne za nepoštovanje odredaba o prebivalištu i boravištu za fizičke osobe iznose od 500 do 5000 kuna.

Stranci se u Austriji prijavljuju u policijskim postajama, a Savezno ministarstvo unutrašnjih poslova vodi Središnji registar boravišta (CRR) te diseminira podatke o prijavama i odjavama boravišta Uredu za statistiku Republike Austrije (Statistik Austria, 2017). Prema Zakonu o nastanjenju i boravištu u Austriji ${ }^{4}$, građani država prostora EEA-a koji borave u Austriji duže od tri mjeseca moraju se registrirati ne kasnije od isteka ta tri.

Za razliku od Austrije, Republika Irska ne zahtijeva registraciju za građane EU-a nakon isteka tromjesečnog razdoblja boravka, već je boravak nakon toga uvjetovan zaposlenjem, studiranjem i sl., kao i u većini ostalih zemalja EU-a. Glavni izvori informacija o procjeni migracijskih podataka jesu Kvartalna nacionalna anketa kućanstava (QNHS - Quarterly National Household Survey) i Anketa o radnoj snazi (LFS - Labour Force Survey). Migracije se procjenjuju i pomoću broja izdanih jedinstvenih brojeva PPS (Personal Public Service Number) koji omogućavaju pristup uslugama socijalne skrbi te javnim uslugama i informacijama. ${ }^{5}$

U Italiji se prijava i odjava boravišta obavlja u općinskim registrima stanovništva, koji šalju podatke o promjenama boravišta Nacionalnom institutu za statistiku Italije putem digitalnog obrasca APR.4. Građani EU-a moraju se registrirati, tj. dobiti dozvolu boravka ako u Italiji namjeravaju boraviti više od tri mjeseca. Zahtjev se podnosi nakon isteka tromjesečnog boravka u Italiji. ${ }^{6}$

Slično kao i Irska, ni Njemačka ne propisuje dozvolu boravka za građane EU-a, ali zahtijeva dokaze o zaposlenju, traženju posla, dovoljnim novčanim sredstvima ili boravku u Njemačkoj duljem od pet godina, ako građanin namjerava boraviti u Njemačkoj dulje od tri mjeseca. Ono što se propisuje kao obveza za sve (njemačke državljane i ostale) jest registracija (pri-

4 Bundesgesetz über die Niederlassung und den Aufenthalt in Österreich (Niederlassungsund Aufenthaltsgesetz - NAG) StF: BGBl. I Nr. 100/2005 (NR: GP XXII RV 952 AB 1055 S. 116. BR: AB 7338 S. 724.).

5 https://www.citizensinformation.ie/en/social_welfare/irish_social_welfare_system/personal_public_service_number.html (17.10. 2019.).

6 Permesso di soggiorno: La guida completa e aggiornata. https://stranieriinitalia.it/attualita/ attualita-sp-754/permesso-di-soggiorno-la-guida-completa-e-aggiornata/ (17. 10. 2019.). 
java) uobičajenog prebivališta $u$ roku od dva tjedna od dolaska, i njegova odjava u roku od dva tjedna od odlaska iz Njemačke. Isto pravilo vrijedi i za selidbu unutar Njemačke, sve prema Saveznom zakonu o registraciji (BMG - Bundesmeldegesetz) (Federal Act on Registration, 2017). Podaci o migracijama pohranjuju se u registru stanovništva i dostupni su preko Federalnog zavoda za statistiku Savezne Republike Njemačke (DESTATIS).

Švedska i Norveška vode registre stanovništva i u obje zemlje građani EU-a ne moraju tražiti dozvolu boravka. ${ }^{7}$ Građani se registriraju u poreznim uredima, iz kojih se podaci prosljeđuju u registar stanovništva te otuda u nacionalne statističke urede. Obje zemlje traže uobičajene uvjete za boravak od godine dana i duži (zaposlenost, studiranje, dovoljno sredstava za uzdržavanje), s razlikom da Norveška obvezuje registraciju nakon tromjesečnog boravka, dok je Švedska takvu obvezu ukinula 2014.

Tablica 1. Načini prikupljanja podataka o migracijama u istraživanim zemljama

Table 1. The modalities of migration data acquisition in the researched countries

\section{Država Način prikupljanja podataka}

Hrvatska Podaci se prikupljaju u Ministarstvu unutarnjih poslova (zakonska obveza prijave/odjave prebivališta, Zakon o prebivalištu, Zakon o strancima).

Federalno ministarstvo unutarnjih poslova prikuplja podatke (zakonska

Austrija je obveza osobe registracija) te ih dostavlja obrađene CRR-u (Centralni registar prebivališta).

Podaci o migracijama prikupljaju se preko digitalnoga administrativnog

Italija obrasca (APR.4) koji prikuplja podatke o odjavama i prijavama iz općinskih registara stanovništva.

Irska Podaci se prikupljaju iz popisa stanovništva, te anketa QNHS i LFS.

Njemačka Podaci se prikupljaju od registracijskih ureda na općinskim razinama, a na osnovi tih podataka dobiva se statistika i unutarnjih i vanjskih migracija.

Podaci se prikupljaju kroz registar stanovništva, kroz Središnji ured za Norveška poreze. Izvješća o imigraciji/emigraciji temelje se na obvezi prijavljivanja u registar stanovništva na općinskoj razini.

Izvori podataka o migracijama temelje se na registraciji osoba koje Švedska Švedska porezna agencija uvodi u središnji registar i dostavlja Središnjem uredu za statistiku Kraljevine Švedske.

Više za Švedsku na: http://wwww.informationsverige.se/en/jag-har-fatt-uppehallstillstand/samhallsorientering/boken-om-sverige/att-forsorja-sig-och-utvecklas-i-sverige/ folkbokforing/; više za Norvešku na: https://www.udi.no/en/want-to-apply/the-registration-scheme-for-eueea-nationals/?c=hrv\#link-884. 
Tablica 2. Rokovi za prijavu/odjavu boravišta/prebivališta u pojedinim zemljama

Table 2. The deadlines for registration/de-registration of the usual residence/permanent residence by specific country

\begin{tabular}{ll}
\hline Država & Prijava/odjava uobičajenog boravišta/prebivališta \\
\hline Hrvatska & $\begin{array}{l}\text { Za odjavu - trajno preseljenje rok je 15 dana; za kraće boravke u inozemstvu } \\
\text { (do godinu dana) postoji obveza obavještavanja MUP-a, ali rok nije } \\
\text { jednosmisleno definiran. }\end{array}$ \\
\hline Austrija & $\begin{array}{l}\text { Dugotrajno boravište moguće je prijaviti unutar tri mjeseca od ulaska } \\
\text { (države EEA-e). }\end{array}$ \\
\hline Italija & $\begin{array}{l}\text { Uobičajeno prebivalište mora se prijaviti nakon isteka tri mjeseca od ulaska } \\
\text { u Italiju ako se planira boraviti u Italiji dulje od tri mjeseca (građani EU-a). }\end{array}$ \\
\hline Irska & Nema definiranog roka za prijavu. \\
\hline Njemačka & $\begin{array}{l}\text { Boravište je obvezno prijaviti u roku od dva tjedna od dolaska i odjaviti u } \\
\text { roku od dva tjedna od odlaska. }\end{array}$ \\
\hline Norveška & Prijavu je obvezno obaviti prije isteka tri mjeseca od dolaska. \\
\hline Švedska & Nema definiranog roka obvezne prijave. \\
\hline
\end{tabular}

\section{Analiza broja useljenih prema hrvatskom državljanstvu}

Podaci iz matrica dvostrukog unosa o iseljenim hrvatskim državljanima iz Hrvatske i useljenim državljanima Hrvatske u pojedinu državu (tablice 3 - 8) pokazuju da je broj iseljenih iz Hrvatske (podaci DZS-a), osim u slučaju Italije, manji nego evidentirani broj useljenih u pojedinu zemlju $u$ istoj kalendarskoj godini. Općenito, najviše iseljenika iz Hrvatske registrirano je u Njemačkoj, a najmanje u Norveškoj. Udio broja iseljenika iz Hrvatske (prema DZS-u) u broju useljenika hrvatskih državljana u pojedinu državu znatno varira: od 6\% za Irsku 2014. i 2015. godine do 66\% za Norvešku 2017. Čini se da u kasnijim godinama udio raste $u$ odnosu na ranije godine, prvenstveno u Austriji, Irskoj, Njemačkoj i Švedskoj. Italija je poseban slučaj gdje je broj odseljenih iz Hrvatske (prema DZS-u) gotovo sve vrijeme veći od broja registriranih građana Hrvatske $u$ Italiji. 
Tablica 3. Odseljeni hrvatski državljani u Austriju (DZS) i doseljeni hrvatski državljani u Austriji (Statistik Austria), 2013. - 2018.

Table 3. Croatian citizens who emigrated to Austria (CBS) and Croatian citizens who immigrated to Austria (Statistics Austria), 2013-2018

\begin{tabular}{ccccc}
\hline Godina & Podaci DZS & Podaci Austrija & Razlika & Udio $^{\text {a }}$ \\
\hline 2013. & 716 & 4183 & 3467 & 0,17 \\
\hline 2014. & 1964 & 6036 & 4072 & 0,33 \\
\hline 2015. & 3208 & 5832 & 2624 & 0,55 \\
\hline 2016. & 2134 & 5097 & 2963 & 0,42 \\
\hline 2017. & 2684 & 5082 & 2398 & 0,53 \\
\hline 2018. & 2553 & ND & ND & ND \\
\hline
\end{tabular}

${ }^{a}$ Udio podataka DZS-a u podacima pojedine zemlje useljenja. Gdje je udio veći od 1, broj evidentiranih iseljenika iz $\mathrm{RH}$ veći je od broja evidentiranih u zemlji useljenja; ND $=$ nije dostupno.

Izvori: Migracije stanovništva Republike Hrvatske u 2013., 2014., 2015., 2016., 2017., 2018., Priopćenje 7.1.2., DZS, Zagreb; Statistik Austria, podaci dobiveni e-poštom na autorov zahtjev.

Tablica 4. Odseljeni hrvatski državljani u Irsku (DZS) i izdani PPS brojevi hrvatskim državljanima u Irskoj (Department of Employment Affairs and Social Protection), 2013. - 2018.

Table 4. Croatian citizens who emigrated to Ireland (CBS) and issued PPS numbers to Croatian citizens in Ireland (Department of Employment Affairs and Social Protection), 2013-2018

\begin{tabular}{ccccc}
\hline Godina & Podaci DZS & Podaci Irska & Razlika & Udio $^{\text {a }}$ \\
\hline 2013. & 31 & 486 & 455 & 0,06 \\
\hline 2014. & 128 & 2091 & 1963 & 0,06 \\
\hline 2015. & 264 & 4342 & 4078 & 0,06 \\
\hline 2016. & 1917 & 5312 & 3395 & 0,36 \\
\hline 2017. & 2675 & 4908 & 2233 & 0,55 \\
\hline 2018. & 2045 & 4346 & 2301 & 0,47 \\
\hline
\end{tabular}

a Udio podataka DZS-a u podacima pojedine zemlje useljenja. Gdje je udio veći od 1, broj evidentiranih iseljenika iz RH veći je od broja evidentiranih u zemlji useljenja; ND = nije dostupno.

Izvori: Migracije stanovništva Republike Hrvatske u 2017., 2018., Priopćenje 7.1.2., DZS, Zagreb; 2013.-2016. posebna obrada, DZS, Zagreb; Državni zavod za statistiku; Department of Employment Affairs and Social Protection, https://www.welfare.ie/en/Pages/Personal-PublicService-Number-Statistics-on-Numbers-Issued.aspx. 
Tablica 5. Odseljeni hrvatski državljani u Italiju (DZS) i doseljeni hrvatski državljani u Italiji (ISTAT), 2013. - 2018.

Table 5. Croatian citizens who emigrated to Italy (CBS) and Croatian citizens who immigrated to Italy (ISTAT), 2013-2018

\begin{tabular}{ccccc}
\hline Godina & Podaci DZS & Podaci Italija & Razlika & Udio $^{\text {a }}$ \\
\hline 2013. & 496 & 665 & 169 & 0,75 \\
\hline 2014. & 817 & 765 & -52 & 1,07 \\
\hline 2015. & 1288 & 673 & -615 & 1,91 \\
\hline 2016. & 795 & 694 & -101 & 1,14 \\
\hline 2017. & 662 & 678 & -16 & 0,98 \\
\hline 2018. & 657 & ND & ND & ND \\
\hline
\end{tabular}

${ }^{a}$ Udio podataka DZS-a u podacima pojedine zemlje useljenja. Gdje je udio veći od 1, broj evidentiranih iseljenika iz $\mathrm{RH}$ veći je od broja evidentiranih u zemlji useljenja; $\mathrm{ND}=$ nije dostupno.

Izvori: Migracije stanovništva Republike Hrvatske u 2013., 2014., 2015., 2016., 2017., 2018., Priopćenje 7.1.2., DZS, Zagreb; Istituto Nazionale di Statistica (ISTAT), http://dati.istat.it/.

Tablica 6. Odseljeni hrvatski državljani u Njemačku (DZS) i doseljeni hrvatski državljani u Njemačkoj (DESTATIS), 2013. - 2018.

Table 6. Croatian citizens who emigrated to Germany (CBS) and Croatian citizens who immigrated to Germany (DESTATIS), 2013-2018

\begin{tabular}{ccccc}
\hline Godina & Podaci DZS & Podaci Njemačka & Razlika & Udio $^{\mathbf{a}}$ \\
\hline 2013. & 2069 & 25.772 & 23.703 & 0,08 \\
\hline 2014. & 7877 & 46.090 & 38.213 & 0,17 \\
\hline 2015. & 12.264 & 60.980 & 48.716 & 0,20 \\
\hline 2016. & 20.343 & 62.109 & 41.766 & 0,33 \\
\hline 2017. & 28.972 & 58.603 & 29.631 & 0,49 \\
\hline 2018. & 21.605 & 57.724 & 36.119 & 0,37 \\
\hline
\end{tabular}

${ }^{a}$ Udio podataka DZS-a u podacima pojedine zemlje useljenja. Gdje je udio veći od 1, broj evidentiranih iseljenika iz RH veći je od broja evidentiranih u zemlji useljenja; ND = nije dostupno.

Izvori: Migracije stanovništva Republike Hrvatske u 2013., 2014., 2015., 2016., 2017., 2018. Priopćenje 7.1.2., DZS, Zagreb; Statistisches Bundesamt (DESTATIS), https://www-genesis. destatis.de/genesis/online/data?operation $=$ abruftabelleBearbeitenElevelindex $=2 \mathcal{E}$ levelid $=15734$ 88610210 Eauswahloperation=abruftabelleAuspraegung AuswaehlenEauswahlverzeichnis=ordn ungsstrukturEauswahlziel=werteabrufEselectionname $=12711-0006 \mathcal{E}$ auswahltext $=$ Ewerteabru $f=$ Werteabruf. 
Tablica 7. Odseljeni hrvatski državljani u Norvešku (DZS) i doseljeni hrvatski državljani u Norveškoj (SSB), 2013. - 2018.

Table 7. Croatian citizens who emigrated to Norway (CBS) and Croatian citizens who immigrated to Norway (SSB), 2013-2018

\begin{tabular}{ccccc}
\hline Godina & Podaci DZS & Podaci Norveška & Razlika & Udio $^{\text {a }}$ \\
\hline 2013. & 59 & 114 & 55 & 0,52 \\
\hline 2014. & 141 & 476 & 335 & 0,30 \\
\hline 2015. & 144 & 584 & 440 & 0,25 \\
\hline 2016. & 223 & 568 & 345 & 0,39 \\
\hline 2017. & 344 & 519 & 175 & 0,66 \\
\hline 2018. & 258 & 531 & 273 & 0,49 \\
\hline
\end{tabular}

${ }^{a}$ Udio podataka DZS-a u podacima pojedine zemlje useljenja. Gdje je udio veći od 1, broj evidentiranih iseljenika iz RH veći je od broja evidentiranih u zemlji useljenja; ND = nije dostupno.

Izvori: Migracije stanovništva Republike Hrvatske u 2017., 2018., Priopćenje 7.1.2., DZS, Zagreb; 2013.-2016. posebna obrada, DZS, Zagreb; Statistisk sentralbyrå (SSB), https://www. ssb.no/en/statbank/table/05476/.

Tablica 8. Odseljeni hrvatski državljani u Švedsku (DZS) i doseljeni hrvatski državljani u Švedskoj (SCB), 2013. - 2018.

Table 8. Croatian citizens who emigrated to Sweden (CBS) and Croatian citizens who immigrated to Sweden (SCB), 2013-2018

\begin{tabular}{ccccc}
\hline Godina & Podaci DZS & Podaci Švedska & Razlika & Udio $^{\text {a }}$ \\
\hline 2013. & 79 & 495 & 416 & 0,16 \\
\hline 2014. & 220 & 1174 & 954 & 0,19 \\
\hline 2015. & 394 & 1450 & 1056 & 0,27 \\
\hline 2016. & 660 & 1569 & 909 & 0,42 \\
\hline 2017. & 786 & 1554 & 768 & 0,51 \\
\hline 2018. & 790 & 1604 & 814 & 0,49 \\
\hline
\end{tabular}

a Udio podataka DZS-a u podacima pojedine zemlje useljenja. Gdje je udio veći od 1, broj evidentiranih iseljenika iz $\mathrm{RH}$ veći je od broja evidentiranih u zemlji useljenja; ND = nije dostupno.

Izvori: Migracije stanovništva Republike Hrvatske u 2013., 2014., 2015., 2016., 2017., 2018., Priopćenje 7.1.2., DZS, Zagreb; Statistiska centralbyrån (SCB), http://www.statistikdatabasen.scb.se/pxweb/en/ssd/START__BE_BE0101__BE0101J/ImmiEmiMedb/table/ tableViewLayout1/?rxid=16bff1c5-50ff-4f5a-a11f-98a0511b3035. 


\section{Analiza broja useljenika kojima je Hrvatska država porijekla}

Brojevi useljenika u pojedine države kojima je država porijekla Republika Hrvatska u pravilu su slični, iako nešto niži od broja onih useljenika s hrvatskim državljanstvom. Razlika je u apsolutnom broju najveća za useljenike u Njemačku, gdje je primjerice 2018. godine useljeno 57.724 državljana Republike Hrvatske, a 51.197 osoba kojima je Hrvatska bila država porijekla. Udjeli u broju useljenika prema podacima iz useljeničkih država nešto su viši od udjela useljenika prema hrvatskom državljanstvu, zbog nešto manjeg broja useljenika kojima je Hrvatska država porijekla. Podaci za Austriju i Irsku nisu dostupni.

Tablica 9. Odseljeni iz Hrvatske u Italiju (DZS) i doseljeni iz Hrvatske u Italiju (izuzev građana Italije) (ISTAT), 2013. - 2018.

Table 9. Citizens who emigrated from Croatia to Italy (CBS) and citizens who immigrated to Italy from Croatia - Italian citizens excluded (ISTAT), 2013-2018

\begin{tabular}{ccccc}
\hline Godina & Podaci DZS & Podaci Italija & Razlika & Udio $^{\text {a }}$ \\
\hline 2013. & 601 & 677 & 76 & 0,89 \\
\hline 2014. & 896 & 718 & -178 & 1,25 \\
\hline 2015. & 1352 & 637 & -715 & 2,12 \\
\hline 2016. & 923 & 642 & -281 & 1,44 \\
\hline 2017. & 794 & 642 & -152 & 1,24 \\
\hline 2018. & 749 & ND & ND & ND \\
\hline
\end{tabular}

${ }^{a}$ Udio podataka DZS-a u podacima pojedine zemlje useljenja. Gdje je udio veći od 1, broj evidentiranih iseljenika iz $\mathrm{RH}$ veći je od broja evidentiranih u zemlji useljenja; ND = nije dostupno.

Izvori: Migracije stanovništva Republike Hrvatske u 2013., 2014., 2015., 2016., 2017., 2018., Priopćenje 7.1.2., DZS, Zagreb; Istituto Nazionale di Statistica (ISTAT), http://dati.istat.it/ 
Tablica 10. Odseljeni iz Hrvatske u Njemačku (DZS) i doseljeni iz Hrvatske u Njemačku (izuzev građana Njemačke) (DESTATIS), 2013. - 2018.

Table 10. Citizens who emigrated from Croatia to Germany (CBS) and citizens who immigrated to Germany from Croatia - German citizens excluded (DESTATIS), 2013-2018

\begin{tabular}{ccccc}
\hline Godina & Podaci DZS & Podaci Njemačka & Razlika & Udio $^{\mathbf{a}}$ \\
\hline 2013. & 2193 & 24.845 & 22.652 & 0,09 \\
\hline 2014. & 7961 & 43.843 & 35.882 & 0,18 \\
\hline 2015. & 12.325 & 57.006 & 44.681 & 0,22 \\
\hline 2016. & 20.432 & 57.155 & 36.723 & 0,36 \\
\hline 2017. & 29.053 & 52.791 & 23.738 & 0,55 \\
\hline 2018. & 21.732 & 51.197 & 29.465 & 0,42 \\
\hline
\end{tabular}

${ }^{a}$ Udio podataka DZS-a u podacima pojedine zemlje useljenja. Gdje je udio veći od 1, broj evidentiranih iseljenika iz RH veći je od broja evidentiranih u zemlji useljenja; $N D=$ nije dostupno.

Izvori: Migracije stanovništva Republike Hrvatske u 2013., 2014., 2015., 2016., 2017., 2018., Priopćenje 7.1.2., DZS, Zagreb; Statistisches Bundesamt (DESTATIS), https://www-genesis. destatis.de/genesis/online/data?operation=abruftabelleBearbeitenElevelindex=2Elevelid $=15734$ 91400654 Eauswahloperation=abruftabelleAuspraegung AuswaehlenEauswahlverzeichnis=ordn ungsstrukturEauswahlziel=werteabrufEselectionname $=12711-0005 \mathcal{E}$ auswahltext $=$ Ewerteabru $f=$ Werteabruf.

Tablica 11. Odseljeni iz Hrvatske u Norvešku (DZS) i doseljeni iz Hrvatske u Norvešku (SSB), 2013. - 2018.

Table 11. Citizens who emigrated from Croatia to Norway (CBS) and citizens who immigrated to Norway from Croatia (SSB), 2013-2018

\begin{tabular}{ccccc}
\hline Godina & Podaci DZS & Podaci Norveška & Razlika & Udio $^{\mathbf{a}}$ \\
\hline 2013. & 63 & 105 & 42 & 0,60 \\
\hline 2014. & 142 & 445 & 303 & 0,32 \\
\hline 2015. & 148 & 519 & 371 & 0,29 \\
\hline 2016. & 223 & 480 & 257 & 0,46 \\
\hline 2017. & 347 & 429 & 82 & 0,81 \\
\hline 2018. & 267 & 435 & 168 & 0,61 \\
\hline
\end{tabular}

a Udio podataka DZS-a u podacima pojedine zemlje useljenja. Gdje je udio veći od 1, broj evidentiranih iseljenika iz RH veći je od broja evidentiranih u zemlji useljenja; ND = nije dostupno.

Izvori: Doseljeno i odseljeno stanovništvo uliz Republike Hrvatske prema zemlji podrijetlal odredišta, Statistika u nizu, 2019, DZS, Zagreb; Statistisk sentralbyrå (SSB), https://www.ssb. no/en/statbank/table/07822/tableViewLayout1/. 
Tablica 12. Odseljeni iz Hrvatske u Švedsku (DZS) i doseljeni iz Hrvatske u Švedsku (SCB), 2013. - 2018.

Table 12. Citizens who emigrated from Croatia to Sweden (CBS) and citizens who immigrated to Sweden from Croatia (SCB), 2013-2018

\begin{tabular}{ccccc}
\hline Godina & Podaci DZS & Podaci Švedska & Razlika & Udio $^{\mathbf{a}}$ \\
\hline 2013. & 97 & 462 & 365 & 0,21 \\
\hline 2014. & 226 & 1008 & 782 & 0,22 \\
\hline 2015. & 401 & 1237 & 836 & 0,32 \\
\hline 2016. & 681 & 1261 & 580 & 0,54 \\
\hline 2017. & 802 & 1201 & 399 & 0,67 \\
\hline 2018. & 814 & 1243 & 429 & 0,65 \\
\hline
\end{tabular}

${ }^{a}$ Udio podataka DZS-a u podacima pojedine zemlje useljenja. Gdje je udio veći od 1, broj evidentiranih iseljenika iz $\mathrm{RH}$ veći je od broja evidentiranih u zemlji useljenja; ND = nije dostupno.

Izvori: Doseljeno i odseljeno stanovništvo uliz Republike Hrvatske prema zemlji podrijetlal odredišta, Statistika u nizu, 2019, DZS, Zagreb; Statistiska centralbyrån (SCB), http://www. statistikdatabasen.scb.se/pxweb/en/ssd/START_BE_BE0101_BE0101J/ImmiEmiFlytt/tablel tableViewLayout1/?rxid=16bff1c5-50ff-4f5a-a11f-98a0511b3035.

\section{RASPRAVA}

Načini prikupljanja podataka o migracijama i registraciji stanovništva pokazuju svu različitost statističkih sustava europskih država. Dok Hrvatska i Austrija podatke prikupljaju kroz sustav unutarnjih poslova, Švedska i Norveška upotrebljavaju porezni sustav za registraciju i pristup građana socijalnim i javnim uslugama. Njemačka i Italija registriraju građane kroz općinski javni sustav, dok Irska procjenjuje broj doseljenog stanovništva tek kroz sustav anketa. Središnje registre stanovništva, kao najbolje oblike vođenja demografskih statistika, imaju Austrija, Švedska i Norveška, dok u Italiji i Njemačkoj postoje decentralizirani registri. Ono što zasigurno utječe na kvalitetu prijavljenih podataka o migraciji jesu rokovi za prijavu uobičajenog prebivališta u pojedinim državama, koji variraju od dva tjedna (u Njemačkoj) do nakon isteka tri mjeseca (Italija), uz države koje ne zahtijevaju prijavu. Na temelju tih podataka, kao i podataka o iseljavanju iz Hrvatske, smatramo da razlika broja odjavljenih građana iz Hrvatske i broja prijavljenih građana Hrvatske u europskim državama, koja u pravilu pokazuje da europske zemlje bilježe veće brojeve od Hrvatske, proizlazi iz dva čimbenika koja su zajedno na djelu: a) načina i razloga (ne)odjavljivanja prebivališta hrvatskih građana u Hrvatskoj i b) načina registracije doseljavanja u europskim državama, posebice s obzirom na rokove registracije. 
Iz rezultata je vidljivo da hrvatski Zakon o prebivalištu (NN, 144/12) upotrebljava pojmove prebivališta i boravišta, umjesto pojma uobičajenog prebivališta. Isto tako, propisuje rok za odjavu u slučaju trajnog preseljenja. No u slučaju privremenog preseljenja u trajanju od jedne godine i dulje zahtijeva obavještavanje nadležnog tijela, ali jasno ne propisuje rok u kojem bi se ta obavijest trebala provesti. Samo ovo može biti dovaljan uzrok zabune koji će građane koji se odseljavaju odvratiti od »odjave«. Pretpostavljamo da građani vrlo često nemaju jasnu ideju o tome koliko će ostati u inozemstvu i zbog toga ne odjavljuju prebivalište u Hrvatskoj niti obavještavaju nadležna tijela da namjeravaju boraviti godinu dana ili dulje. No namjera boravka od godine dana ili dulje, iako temelj za definiranje migracije $\mathrm{u}$ Europskoj uniji, $\mathrm{u}$ istom zakonskom članku nigdje nije izrijekom navedena, nego formulacija glasi: »Ako osoba napušta prebivalište u trajanju duljem od godinu « (Zakon o prebivalištu, NN, 144/12), što se može protumačiti kao obveza odjave (tj. obavijesti nadležnom tijelu) tek nakon protekle jedne godine $\mathrm{u}$ inozemstvu. Ako se uzme $\mathrm{u}$ obzir da neke zemlje zahtijevaju registraciju već nakon dva tjedna, a većina unutar ili nakon tri mjeseca, jasno je da čak i pridržavanje slova zakona može rezultirati većim brojem prijavljenih useljenika u europskim državama nego prijavljenih privremeno odseljenih iz Hrvatske.

No osim razlika u načinima prijave/odjave valja uzeti u obzir i drugi aspekt odjavljivanja iz Hrvatske, a to su različiti poticaji da se to ne učini (Reeger, 2009). Uz nesigurnost dobivanja radnog mjesta $u$ inozemstvu i sezonski karakter rada, važan aspekt izbjegavanja odjave iz Hrvatske jest gubljenje određenih socijalnih prava, prvenstveno zdravstvenog osiguranja. Naime u Hrvatskoj su zdravstvene usluge $\mathrm{u}$ pravilu jeftinije nego $\mathrm{u}$ zapadnoeuropskim zemljama. Hrvatski zavod za zdravstveno osiguranje ovako je odgovorio na novinarski upit o tome: »Osoba ne može biti zdravstveno osigurana u dvije države članice EU, već je osigurana u državi u kojoj radi, a na području druge države u kojoj živi ostvaruje pravo na punu zdravstvenu zaštitu, kao i svi drugi zdravstveno osigurani građani u toj državi, a na teret zdravstvenog osiguranja u državi rada. Npr. aktivni osiguranik radi u Hrvatskoj, a živi u Sloveniji. Tada na području Slovenije ima pravo na punu zdravstvenu zaštitu, a na teret Hrvatskog zavoda za zdravstveno osiguranje (U Hrvatskoj više ljudi koristi zdravstvene usluge..., 2019).

No, isto tako, prema Zakonu o obveznom zdravstvenom osiguranju, osoba koja ima prebivalište u Hrvatskoj ima pravo na zdravstvenu zaštitu, čak 
i ako nije zaposlena ( $N N, 80 / 13)$. Stoga ako osoba npr. i prebiva i radi u Irskoj, tamo ima pravo na zdravstvenu zaštitu na teret irskoga zdravstvenog sustava, a ako nije odjavila prebivalište u Hrvatskoj, ima isto pravo i u Hrvatskoj, ako se vodi kao nezaposlena osoba, što je povreda pravila o nemogućnosti zdravstvenog osiguranja u dvije države. Zbog toga postoje inicijative umrežavanja zdravstvenih sustava unutar EU-a kako bi se takva praksa izbjegla (Bratonja Martinović, 2019), no čini se da policijski i pravosudni sustav ne čine dovoljno kako bi se utvrdio pravi broj onih koji prebivaju na području Hrvatske. Provjeru prebivališta utvrđuju policijski službenici terenskim izvidom, prema vlastitim saznanjima i prema dojavama građana. Mišljenja smo da policijskim službenicima ovo nije prioritet ili da jednostavno nemaju dovoljno resursa za ovu djelatnost. U prilog ovoj tvrdnji ide i broj prijavljenih prekršaja o povredi propisa o prebivalištu, boravištu i osobnim iskaznicama, koji je u 2018. iznosio samo 540 prijavljenih prekršaja i 337 osuđenih (Počinitelji prekršaja u 2018.). Valja naglasiti da u te brojeve ulaze sve vrste prekršaja propisa o boravištu i prebivalištu, ali i osobnim iskaznicama, i za građane koji stvarno prebivaju u Hrvatskoj, ali i one s »fiktivnim « hrvatskim prebivalištem.

Usporedba broja odseljenih i useljenih hrvatskih građana, kao i onih koji su se odselili iz Hrvatske i koji su prijavili državu porijekla Hrvatsku jest, osim $\mathrm{u}$ slučaju Italije, u skladu s tezom da je prijavljeni broj odseljenih u pravilu manji od prijavljenog broja useljenih. Brojevi onih kojima je država porijekla Hrvatska nešto su manji od brojeva onih koji su se uselili kao hrvatski državljani, što sugerira da su se hrvatski državljani useljavali u europske zemlje i iz drugih država. No ovo ipak ne znači da se na temelju tih podataka može sigurno utvrditi broj hrvatskih državljana koji su se uselili iz drugih država osim Hrvatske, zbog već navedenog problema »fiktivnih « prebivališta hrvatskih državljana iz drugih zemalja u Hrvatskoj. Zbog čega je Italija jedini slučaj gdje je broj prijavljenih odjava iz Hrvatske gotovo uvijek viši od broja prijava učestalog prebivališta u Italiji, nije jednostavno utvrditi. Moguće je da Italija nije tako privlačna zemlja za ekonomske migrante iz Hrvatske, tj. da je struktura migranata drugačija negoli onih prema drugim zemljama. Isto tako, moguće je da su migranti u Italiju većim brojem oni koji se namjeravaju stalno nastaniti u njoj, pa češće odjavljuju svoje prebivalište u Hrvatskoj, a potrebno im je neko vrijeme da prijave uobičajeno prebivalište $u$ Italiji. Postoje i anegdotalni primjeri duljeg trajanja procesa registracije u Italiji. ${ }^{8}$

Vidi npr.: How to apply for Residency in Italy as an EU Citizen, https://anamericaninrome.com/wp/2018/04/how-to-apply-for-residency-in-italy-as-an-eu-citizen/ (29. 10. 2019.). 
U ostalim slučajevima, uz već raspravljenu odgodu odjave prebivališta $u$ Hrvatskoj, čini se da rokovi prijave u državi odredišta utječu na veći broj registriranih. Polazimo od pretpostavke da useljenici imaju više poticaja registrirati se u državi u koju se useljavaju, gdje očekuju ili imaju zaposlenje, stanuju, plaćaju poreze i ostvaruju socijalne dobitke. Sama činjenica da je takav rok u većini država tri mjeseca, uz izostanak odjave iz Hrvatske, čini broj useljenih u jednoj godini višim od broja iseljenih iz Hrvatske. Instruktivan je primjer Njemačka, gdje je rok i prijave i odjave najkraći. Tu je imigracija hrvatskog stanovništva u apsolutnim iznosima najveća, ali je i najveća apsolutna razlika broja prijavljenih u Njemačkoj i broja iz hrvatske službene statistike. Budući da je razlika toliko velika i da se u Njemačkoj svaka odjava i prijava mora provesti u roku od četrnaest dana, čini se da se tijekom jedne godine veliki broj građana Hrvatske useli u Njemačku, ali se iz nje i iseli, $\mathrm{i} / \mathrm{ili}$ se dio hrvatskih građana višekratno tijekom godine useljava i iseljava iz Njemačke. Njemačka statistika ne broji osobe koje se useljavaju ili iseljavaju, nego »slučajeve « useljavanja i iseljavanja (Ruehl, 2009). Potvrda ovoj dinamici dolazi i od broja odseljenih iz Njemačke. Prema njemačkim podacima, prema Hrvatskoj se 2018. iselilo 25.906 osoba koje nisu Nijemci prema nacionalnosti (DESTATIS, 2019). S druge strane, ukupni broj useljenih u Hrvatsku tijekom 2018. iznosi 26.029, a iz same Njemačke 3232. Takva razlika najbolje se može objasniti samo velikom fluktuacijom hrvatskih građana između Hrvatske i Njemačke, uz češće i ažurnije prijavljivanje/odjavljivanje u Njemačkoj nego u Hrvatskoj (Pokos, 2017). Slična dinamika, iako manjeg opsega zbog duljih rokova prijave, prisutna je vjerojatno između Hrvatske i drugih promatranih zemalja.

\section{ZAKLJUČAK}

Zaključno, sustavi prijave i odjave uobičajenog prebivališta, ali i sustavi vođenja statistika o migrantima uvelike se razlikuju između promatranih zemalja. Dok Austrija i Hrvatska registraciju provode kroz sustav unutrašnjih poslova, Italija i Njemačka provode je kroz općinska tijela, a Švedska i Norveška kroz porezni sustav. Irska, s druge strane, nema poseban sustav registracije građana iz zemalja EU-a, niti vodi službene statistike o doseljenima i odseljenima. Razlike postoje i u rokovima prijave/odjave, koji variraju od četrnaest dana do više od tri mjeseca. Udjeli hrvatskih građana koji se iseljavaju iz Hrvatske (prema podacima DZS-a) u broju hrvatskih državljana i onih kojima je Hrvatska zemlja porijekla, prema podacima šest 
europskih država, variraju u velikom rasponu, od 6 do 81 posto, a u slučaju Italije udjeli su veći od jedan.

Razlike u podacima o migraciji između Hrvatske i europskih zemalja nastaju zbog načina registracije doseljavanja u europskim zemljama, posebice $s$ obzirom na rokove registracije, i načina i razloga (ne)odjavljivanja prebivališta hrvatskih građana u Hrvatskoj. Taj će problem postojati i dalje, sve dok se ne promijene načini registracije prebivališta kako na razini Hrvatske tako i na razini Europske unije. U Republici Hrvatskoj nužno je uvesti pouzdan i točan registar stanovništva te zamijeniti pojmove prebivališta i boravišta pojmom uobičajenog prebivališta. Registracija novoga uobičajenog prebivališta bila bi nužna nakon tri mjeseca boravka na određenoj adresi, kao za hrvatske državljane tako i za građane EU-a koji se useljavaju u Hrvatsku, uz izjašnjavanje o namjeri boravka barem godinu dana od ulaska u Hrvatsku. U takvu slučaju trebalo bi razmisliti o tome da prijave i odjave ne budu u sferi policijskog djelovanja, nego općinskih registracijskih ureda, koji bi podatke dostavljali središnjem registru. Takav sveobuhvatni registar bio bi dostupan policijskim, pravosudnim, poreznim i zdravstvenim tijelima, tako da manipulacije mjestom prebivališta više ne bi bile moguće. Dakako, provjera ažurnosti podataka trebala bi biti češća i obuhvatnija nego dosad. Postoje najave da će se ovakav sustav uvesti u Hrvatskoj, što je i preporuka EU-a (Laušić, 2019).

Ažurnost sustava neće moći biti moguća bez razmjene podataka s ostalim zemljama članicama, što dovodi do nužnih promjena na razini cijele Europske unije. Zahtjevi za ujednačavanjem (harmonizacijom) nacionalnih sustava za demografsku statistiku postoje već duže (Kupiszewska i Nowok, 2008; Raymer, 2017; Thierry i sur., 2005) i prisutan je u Uredbi (EZ) br. 862/2007 o statistici Zajednice o migracijama i međunarodnoj zaštiti, no ona ne obvezuje zemlje članice na promjenu nacionalnih načina prikupljanja podataka. Veliki dio ujednačavanja već je proveden, tako da je 2005. dvadeset članica ispunjavalo uvjete dostupnosti migracijskih statistika (Thierry i sur., 2005). Prema istom članku, uzor cijeloj Europskoj uniji treba biti sustav razmjene podataka između nordijskih država, koje učinkovito i usporedivo razmjenjuju podatke o migracijama između svojih država. Takav tip suradnje trebao bi potaknuti i ostale članice na sklapanje bilateralnih ugovora koji bi osigurali usporedivost i dostupnost podataka u cijeloj Europskoj uniji (Thierry i sur., 2005).

Ovo nije samo administrativno pitanje jer neusporedivost statistika o migraciji ima stvarne posljedice. Ujednačavanjem statistika omogućili bi se jasniji 
znanstveni uvidi u prirodu i razloge migracija između zemalja te bi se na temelju toga mogle jasnije i preciznije planirati mjere koje bi ublažile negativne aspekte migracija. Posebice se to odnosi na zemlje iz kojih se iseljava jer bi točnijim uvidom $u$ to kamo i kako se njihovi građani iseljavaju mogle poraditi na mjerama ublažavanja potisnih čimbenika emigracije. Također, ujednačenjem podataka o osobama koje se iseljavaju izbjegle bi se zlouporabe socijalnih, zdravstvenih i poreznih sustava i omogućilo njihovo učinkovitije i pravednije funkcioniranje. Konačno, boljom spoznajom o dinamici migracija osnažio bi se odnos između zemalja porijekla i zemalja useljenja te samim time i gospodarska i društvena kohezija unutar Europske unije.

\section{LITERATURA}

Bilsborrow, R. E. (2016). Concepts, Definitions and Data Collection Approaches, u: M. J. White (ur.). International Handbook of Migration and Population Distribution. Dordrecht: Springer, 109-156.

Bratonja Martinović, L. (2019). Plati pa se liječi: HZZO vas sad nalazi i u Irskoj! “Eliminirat ćemo sve koji nemaju ovo pravo.", http://www.novilist.hr/Vijesti/Hrvatska/Platipa-se-lijeci-HZZO-vas-sad-nalazi-i-u-Irskoj!-Eliminirat-cemo-sve-koji-nemaju-ovopravo (22. 10. 2019.).

Brown, S. K. i Bean, F. D. (2016). Conceptualizing Migration: From Internal/International to Kinds of Membership. u: M. J. White (ur.). International Handbook of Migration and Population Distribution. Dordrecht: Springer, 91-108.

Bryan, T. (2004). Basic Sources of Statistics. u: J. S. Siegel i D. A. Swanson (ur.). The Methods and Materials of Demography. London: Elsevier Academic Press, 9-42.

Bundesgesetz über die Niederlassung und den Aufenthalt in Österreich (Niederlassungsund Aufenthaltsgesetz - NAG), StF: BGBl. I Nr. 100/2005 (NR: GP XXII RV 952 AB 1055 S. 116. BR: AB 7338 S. 724.). https://www.ris.bka.gv.at/GeltendeFassung.wxe?A bfrage $=$ Bundesnormen\&Gesetzesnummer=20004242 (22. 10. 2019.).

Castles, S., de Haas, H. i Miller, M. J. (2014). The Age of Migration: International Population Movements in the Modern World (Fifth Edition). New York: Palgrave Macmillan.

Edmonston, B. i Michalowski, M. (2004). International Migration, u: J. S. Siegel i D. A. Swanson (ur.). The Methods and Materials of Demography. London: Elsevier Academic Press, 455-492.

Federal Act on Registration [Bundesmeldegesetz], Federal Law Gazette, I p. 1084, 2013; I p. 2745, 2017, http://www.gesetze-im-internet.de/englisch_bmg/englisch_bmg. html\#p0184

International Organization for Migration (IOM) (2019). Glossary on Migration. Geneva, https://publications.iom.int/system/files/pdf/iml_34_glossary.pdf.

Jurić, T. (2017). Suvremeno iseljavanje Hrvata u Njemačku: Karakteristike i motivi, Migracijske i etničke teme, 33 (3), 337-371, doi: https://doi.org/10.11567/met.33.3.4

Kupiszewska, D. i Nowok, B. (2008). Comparability of statistics on international migration flows in the European Union, u: J. Raymer i F. Willekens (ur.). International Migration in Europe Data, Models and Estimates. Chichester: John Wiley \& Sons, 41-72. 
Laušić, F. (2019). Otkrivamo: ukida se popis stanovništva! Država uvodi registar u kojem će stalno znati tko s kim živi, tko gdje radi, a tko u stanu ima WC s kotlićem, Jutarnji list, 03. rujna, https://www.jutarnji.hr/vijesti/hrvatska/otkrivamo-ukida-sepopis-stanovnistva-drzava-uvodi-registar-u-kojem-ce-stalno-znati-tko-s-kim-zivitko-gdje-radi-a-tko-u-stanu-ima-wc-s-kotlicem/9309482/ (29. 10. 2019.)

Migration Data Portal (2019a). Migration statistics, https://migrationdataportal.org/ data?i=stock_abs_\&t=2019\&m=1\&rm49=150 (17. 10. 2019.)

Migration Data Portal (2019b). Migration and trade. https://migrationdataportal.org/ themes/migration-and-trade (17. 10. 2019.)

Migration Data Portal. (2019c). Remittances. http://migrationdataportal.org/themes/ remittances (17. 10. 2019.)

Pokos, N. (2017). Osnovna demografska obilježja suvremenog iseljavanja iz Hrvatske, Političke analize, 31, 16-23.

Poulain, M. (2008). European migration statistics: Definitions, data and challenges, u: M. Barni i G. Extra (ur.). Mapping Linguistic Diversity in Multicultural Contexts. New York: Mouton de Gruyter, 43-68.

Rajković Iveta, M. i Horvatin, T. (2017). Suvremeno iseljavanje iz Hrvatske u Irsku s posebnim osvrtom na mlade iz Slavonije, Migracijske i etničke teme, 33 (3), 247-274, doi: https://doi.org/10.11567/met.33.3.1

Raymer, J. (2016). Migration in Europe, u: M. J. White (ur.). International Handbook of Migration and Population Distribution. Dordrecht: Springer, 371-388.

Raymer, J. (2017). Measuring flows of international migration. IZA World of Labor, 354, doi: https://doi.org/10.15185/izawol.354

Raymer, J., Wiśniowski, A., Forster, J. J., Smith, P. W. F. i Bijak, J. (2013). Integrated Modeling of European Migration, Journal of the American Statistical Association, 108 (503), 801-819, doi: https://doi.org/10.1080/01621459.2013.789435

Reeger, U. (2009). Austria, u: H. Fassmann, U. Reeger, i W. Sievers (ur.). Statistics and Reality: Concepts and Measurements of Migration in Europe. Amsterdam: Amsterdam University Press, 111-130.

Ruehl, S. (2009). Germany, u: H. Fassmann, U. Reeger, i W. Sievers (ur.). Statistics and Reality: Concepts and Measurements of Migration in Europe. Amsterdam: Amsterdam University Press, 131-150.

Sander, N., Abel, G. J. i Riosmena, F. (2014). The future of international migration, u: W. Lutz, W. P. Butz i S. Kc (ur.). World Population \& Human Capital in the Twenty-First Century: An Overview. Oxford: Oxford University Press, 333-396.

Statistik Austria (2017). Meta information (Definitions, comments, methods, quality) on Migration Statistics. Statistik Austria, Bundesanstalt Statistik Österreich.

Thierry, X., Herm, A., Kupiszewska, D., Nowok, B. i Poulain, M. (2005). How the UN recommendations and the forthcoming EU regulation on international migration statistics are fulfilled in the 25 EU countries?. Tours: International Union for the Scientific Study of Population XXV International Population Conference.

U Hrvatskoj više ljudi koristi zdravstvene usluge nego što u njoj živi, 034portal.hr, 27. veljače, https://www.034portal.hr/u-hrvatskoj-vise-ljudi-koristi-zdravstveneusluge-nego-sto-u-njoj-zivi-879 (17. 10. 2019.).

United Nations (UN) (1998). Recommendations on Statistics of International Migration, Revision 1. United Nations, Department of Economic and Social affairs. 
Willekens, F. (2016). Migration Flows: Measurement, Analysis and Modeling, u: Michale J. White (ur.). International Handbook of Migration and Population Distribution. Dordrecht: Springer, 225-244.

Zakon o obveznom zdravstvenom osiguranju, Narodne novine, 80/13.

Zakon o prebivalištu, Narodne novine, 144/12.

Župarić-Iljić, D. (2016). Iseljavanje iz Republike Hrvatske nakon ulaska u Europsku uniju. Zagreb: Friedrich Ebert Stiftung - Zagreb.

\section{IZVORI}

Department of Employment Affairs and Social Protection, 2019, https://www.welfare.ie/ en/Pages/Personal-Public-Service-Number-Statistics-on-Numbers-Issued.aspx (16. 10. 2019.).

Istituto Nazionale di Statistica (ISTAT), 2019, http://dati.istat.it/ (11. 10. 2019.).

Migracije stanovništva Republike Hrvatske u 2013., 2014., 2015., 2016., 2017., 2018., Priopćenje 7.1.2., Državni zavod za statistiku, Zagreb.

Počinitelji prekršaja u 2018., Statistička izvješća 1652, Državni zavod za statistiku, Zagreb.

Statistički ljetopis Republike Hrvatske 2018., Državni zavod za statistiku, Zagreb.

Statistika u nizu, 2019., Doseljeno i odseljeno stanovništvo u/iz Republike Hrvatske prema zemlji podrijetla/odredišta, Državni zavod za statistiku, Zagreb.

Statistisches Bundesamt (DESTATIS), Statistisches Bundesamt Deutschland - GENESIS, https://www-genesis.destatis.de/genesis/online/data?operation=abruftabelleBearbei ten\&levelindex=2\&levelid=1574028880655\&auswahloperation=abruftabelleAusprae gungAuswaehlen\&auswahlverzeichnis=ordnungsstruktur\&auswahlziel=werteabru f\&code $=12711-0005 \&$ auswahltext=\&werteabruf=Werteabruf (11. 10. 2019.).

Statistiska centralbyrån (SCB), 2019,

http://www.statistikdatabasen.scb.se/pxweb/en/ssd/START__BE__BE0101

BE0101J/ImmiEmiMedb/table/tableViewLayout1/?rxid=16bff1c5-50ff-4f5a-a11f98a0511b3035 (16. 10. 2019.).

Statistisk sentralbyrå (SSB),

https://www.ssb.no/en/statbank/table/07822/tableViewLayout1/ (16. 10. 2019.). 


\title{
The Differences in Migration Data Collection: A Comparison between Croatia and Selected European Countries
}

\author{
Dario Pavić, Ida Ivanović
}

\begin{abstract}
SUMMARY
Migration is one of the demographic processes that has shaped the modern world most profoundly. It is estimated that the global number of migrants reached 272 million in 2019 and that international migrants make up 3.5\% of the world population. These figures reveal that migration shapes the modern world not only in economic terms, through the growth of trade and remittances, but also in terms of culture, gender, ethnicity, and identity. In a world of declining fertility, migration is becoming the main factor in the spatial distribution of the world population. However, migration is still one of the most poorly defined and measured demographic processes, lacking standardised procedures between countries, which prevents international comparability of data. Also, an overarching theory of migration does not exist, and instead we are left with several perspectives.
\end{abstract}

The two main aspects of any definition of migration are (1) a change in place of usual residence, and (2) crossing an established political/administrative border. One term essential for defining migration is the place of usual residence, a place where a person lives or spends most of his/her daily rest. This definition is important since shorter periods of absence from this place do not count as migration (tourist travel, pilgrimages, etc.). The length of absence is the most important condition; the EU defines immigration as establishing a new usual residence that lasts or is expected to last at least 12 months. Another challenge to the definition of migration are the recommendations of the UN on the international migration statistics where there is a distinction between "short-term migrants" (those who reside in the country of immigration for 91 to 365 days), and "long-term migrants" (those who reside in the country of immigration for more than a year). Some countries do not abide by these recommendations, so the time frame for attaining a resident status differs among countries. Also, the manner of producing statistics on migrations differs among countries as well. There are several ways of producing these statistics, most notably by using border crossing data, censuses, surveys, and population registers, the latter being considered the "golden standard" of migration data.

The aim of this paper is to compare the ways of collecting data on migrations and the deadlines for registering residence in Croatia and six other European countries, to explain the discrepancy in the number of annual migrants in the data for Croatia and the other countries, from 2013 (the year of Croatia's accession to the EU) until 2018. It has been established that deregistration from the origin country is far less pronounced than registration in the country of destination due to the different incentives for the migrants. In the case of Croatia, the main problem is the unknown number of Croatian citizens who reside in neighbouring countries (mostly Bosnia and Herzegovina and Serbia). We try to solve this problem by separately analysing the statistics on migrants with Croatian citizenship and migrants from the origin country of Croatia. However, there is an unknown number of Croatian citizens re- 
siding in neighbouring countries with registered residence in Croatia (so-called "fictive residents") and isolating these individuals in migration statistics is not possible.

Six European countries were chosen for the analysis: Austria, Germany, Ireland, Italy, Norway and Sweden, mostly for their economic power, but for other reasons as well, ranging from strong cultural ties and existing Croatian diasporas (Italy, Germany, Austria), to favourable immigration laws, a mostly Roman Catholic population (Ireland) and a strong welfare state (Norway and Sweden). The analysis itself consists of two parts: the comparative analysis of the legal framework for establishing residence in a specific country, with emphasis on the deadline for registering usual residence, and the analysis of the reported number of immigrants in a specific country, compared to the number of deregistered Croatian citizens (and those whose country of origin is Croatia). The numbers of registered Croatian citizens in specific European countries and deregistered citizens from Croatia were obtained through the official statistics bureaus' websites, except for Austria, where the data were sent to the authors on request. Also, the numbers of Croatian citizens registered in Ireland were estimated by the number of Personal Public Service Numbers (PPSNs) issued to Croatian citizens every year.

Croatian law differentiates between permanent and temporary emigration. Those who leave the country permanently must deregister within 15 days of leaving. For those leaving Croatia temporarily, the law is not as exact; they must notify the police (where all registration and deregistration takes place), but the deadline for notification is not specified. This alone can demotivate emigrating citizens from deregistering. In Austria, the registration process also falls under the jurisdiction of the police. Here, immigrants from EU countries must register if they want to reside in the country for longer than three months. The deadline for registration is the last day of the three-month period. The data on migration is collected and kept in the population register.

Ireland does not require registration of EU citizens and does not keep a population register. Data on migration are gathered through the Quarterly National Household Survey and Labour Force Survey. The number of Croatian immigrants is estimated by the annual number of issued Personal Public Service Numbers. In Italy, registration takes place in municipality registration offices that keep municipal population registers. EU citizens must register if they plan to spend more than three months in Italy, and they must do so after the three months have passed.

Germany does not require a residence permit, yet all persons, whether German nationals or foreigners, must register their usual residence within 14 days of arrival, and deregister within 14 days of either a departure or a change of usual residence within Germany. Germany keeps a population register. Likewise, Norway and Sweden keep population registers as well and do not require a residence permit, the only difference between these two countries being that Norway requires registration after the three-month period, while Sweden does not.

As for the data on migration flows from Croatia to these six European countries, all the data on immigration to those countries from their respective statistics bureaus cite higher numbers than the data on emigration from Croatia from the Croatian Bureau of Statistics, except Italy. These differences are approximately the same for the data on Croatian citizens and the data for persons coming from Croatia as the country of origin. The annual share of the Croatian emigrant data in the European countries' immigrant data range from $6 \%$ to $67 \%$. We interpret these discrepancies 
by two main processes. Firstly, since Croatian law is not unequivocal on the deadline for deregistration, many Croatian emigrants simply do not know when to deregister, in addition to not knowing how long they will stay in the country of immigration. Furthermore, there are negative consequences for deregistering. Croatian citizens would lose many health and social benefits in Croatia if they deregister. There is also evidence that the Croatian interior affairs and judicial system are not very efficient in punishing those that do not deregister. Secondly, most of the countries require registration at the end of three months, Germany even after 14 days. Since immigrants have more incentives to register in the new country, the numbers of immigrants are higher than those of emigrants from Croatian data. These numbers can also be misleading, as in the case of Germany, where there are many more annual emigrants to Croatia than the Croatian data reveal, meaning that people come and go to Germany several times annually.

In conclusion, this research reveals the imperfections in the registration process, the differences in the logic and procedure of data acquisition, and dissemination, and different traditions of data acquisition throughout Europe. It is therefore of vital interest to harmonise the data gathering process by unifying the definitions of migrations, the registration process and data dissemination. For Croatia, the imperative is to adopt the concept of usual residence, to implement the population register and to change the laws on residence accordingly. The ideal for all European countries should be the cooperation between Nordic countries where the process of data sharing is efficient and the statistics are fully comparable.

KEY WORDS: emigration, population register, usual residence, Croatia, migration flow 